\title{
Climatic Variables and Their Effects on Phenolic Maturation and Potassium Uptake in Cabernet Sauvignon Wines
}

\author{
Tiago Stein ${ }^{1}$, Ivan Ricardo Carvalho ${ }^{2}$, Renata Gimenez Sampaio Zocche ${ }^{1}$, Suziane Antes Jacobs ${ }^{1}$, \\ Vinícius Jardel Szareski ${ }^{2}$, Fernando Zocche ${ }^{1}$, Keila Garcia Aloy ${ }^{1}$, Lucas de Vargas dos Santos ${ }^{1}$, \\ Hyoran Caius Genindo Barreto Martins ${ }^{1}$, Tiago Corazza da Rosa ${ }^{2} \&$ Velci Queiróz de Souza ${ }^{1}$ \\ ${ }^{1}$ Federal Universityof Pampa, Dom Pedrito, RS, Brazil \\ ${ }^{2}$ Federal Universityof Pelotas, Capão Leão, RS, Brazil \\ Correspondence: Renata Gimenez Sampaio Zocche, Federal University of Pampa, Avenida Maria Anunciação \\ Gomes Godoy, 1650-96413-170-Bagé, Dom Pedrito, RS, Brazil. E-mail: sampaiozocche@hotmail.com
}

Received: February 26, $2018 \quad$ Accepted: April 11, $2018 \quad$ Online Published: July 15, 2018

doi:10.5539/jas.v10n8p388 URL: https://doi.org/10.5539/jas.v10n8p388

\begin{abstract}
The aimed at identifying and understanding the relationships of phenolic maturation and potassium uptake dynamics jointly with climatic variables for Cabernet Sauvignon variety. The experiment was carried out in Dom Pedrito, Rio Grande do Sul-Brazil, in the 2016 growing season. The experimental design was randomized blocks with treatments arranged in three replicates. The physical-chemical characteristics were measured: Density, Glucometric degree, Hydrogen ionic potential, Titratable Total Acidity, Total polyphenol index, Potassium, Phenolic maturity index. The periods preceding grapes phenolic maturation directly influence the physical and chemical conformity of must and wine. Potassium, $\mathrm{pH}$ and total acidity directly influence the poor phenolic maturation of Cabernet Sauvignon. Minimum and maximum air temperature, thermal amplitude, incident solar radiation and accumulated rainfall interfere in the photosynthetic dynamics, potassium accumulation in the grapes and phenolic maturation of Cabernet Sauvignon.
\end{abstract}

Keywords: enology, grape production, physicochemical caracteres, potassium

\section{Introduction}

The Brazilian region known as Campanha Gaúcha, located in southern Rio Grande do Sul state, has been standing out by producing fine wines. This region is the second largest producer of fine wines in Brazil, accounting for $31 \%$ of the country's production. The wineries from this region offer more than 300 commercial brands available for the market (Sinimbu, 2015; Zanette et al., 2016). Among the varieties produced in this region, Cabernet Sauvignon is highlighted. This variety accounts for a large fraction of the wines produced, being characterized as a fine variety for vinification, and it is the most cultivated variety in Brazil (Giovannini, 2001; Zocche et al., 2016a, 2016b; Jacobs et al., 2016). Cabernet Sauvignon comes from the Bordeaux region of France.It was introduced in Brazil in 1921, but only after 1980, there was an increase in its production area.Its cultivation is intended for aged or young red wines production (Rizzon \& Miele, 2002).

In wine production, an important character to be analyzed is the amount of potassium in the must and wine, being this one of the main nutrients required for the grapevine, and one of the macronutrients most required by this species (Ciotta et al., 2016). Potassium is a dominant cation in wines at average concentration of $1 \mathrm{~g} \mathrm{~L}^{-1}$ (Riberau-Gayon et al., 2003). Wines elaborated from Cabernet Sauvignon grapes in the CanoanhaGaúcha region presented $1936.4 \mathrm{mg} \mathrm{L}^{-1}$ of this nutrient (Zocche et al., 2017). High values of potassium in wines are related to the decrease of total acidity and increase of $\mathrm{pH}$, being the magnitude of wine $\mathrm{pH}$ dependent on type and concentration of potassium cations, and wine acidity (Rizzon \& Miele, 2002). Elevated levels of potassium in grapes and must may reduce total sugars and consequently jeopardize fermentation (Walker \& Blackmore, 2012).

The influence of potassium on $\mathrm{pH}$ and total acidity is consolidated, however, potassium binds to tartaric acid $(\mathrm{H} 2 \mathrm{~T})$ to form a salt called potassium bitartrate $\left(\mathrm{C}_{4} \mathrm{H}_{6} \mathrm{O}_{5} \mathrm{~K}\right)$. On the other hand, its precipitation decreases levels of tartaric acid and total acidity, but the wine's $\mathrm{pH}$ is increased. Thus, $\mathrm{pH}$ and total acidity are directly related to staining stability of red wines, as the anthocyanins stability is dependent of a pH smaller than 4.0. In this context, 
potassium excess in wine results in $\mathrm{pH}$ rise and total acidity reduction, staining instability with anthocyanins reduction (Zocche et al., 2016b). High potassium levels raise $\mathrm{pH}$ and considerably reduce titratable total acidity, contributing to wine susceptibility to oxidation (Mpelasoka et al., 2003). Likewise, $\mathrm{pH}$ magnitude influences on wines microbiological stability, aspH elevation exposes wines to microbiological and physico-chemical variations that harm stability (Rizzon \& Miele, 2002).

Since $\mathrm{pH}$ and total acidity are important characteristics for wine quality, and directly influenced by potassium concentration, it is necessary to understand the dynamics of potassium uptake by plants. The absorption of this macronutrient by vines is influenced by the growing environment edapho-climatic characteristics, as vines varieties perform according to genotypes x environments interaction (Leão \& Silva, 2003; Zocche et al., 2017). The climatic variables might directly influence on physical-chemical characteristics of wines, where air temperature and rainfall directly affects vines phenological behavior, and amplitudes of air temperatures are determinant for physico-chemical characteristics of the wines produced (Kishino \& Marur, 2007).

The response of grapevines to climatic conditions and their effects on biosynthesis, translocation, degradation and accumulation of substances in grapesis transferred to wines, defining color, aroma, taste, body, acidity and structure (Zanus \& Tonietto, 2012). Potassium and other important traits in grapes and wines are influenced by climatic factors. According to Togores (2011), the increase in photosynthetically active leaf surface of the vines exposed to solar radiation tends to result in wines with lower potassium content. Among the characters measured, phenolic maturation is often used as a criterion to monitor tannin maturation and anthocyanins extractability, predicting the harvest, and when the grape has higher levels of polymerized tannins, they will be essential for wines sensorial quality and anthocyanins extractability levels. According to Zamora (2003), phenolic maturation comprises the optimal level of maturation to produce high quality red wines.

In order to better understand the determining mechanisms of potassium uptake in Cabernet Sauvignon variety, it is necessary to relate climatic variables of the region to phenolic maturation stage of grapes before harvest. In this view, potassium amounts verified in the must are related to $\mathrm{pH}$, titratable acidity and other characters of interest for wine production. Therefore, this work aimed at identifying and understanding the relationships of phenolic maturation and potassium uptake dynamics jointly with climatic variables for Cabernet Sauvignon variety.

\section{Material and Methods}

The experiment was carried out in Dom Pedrito, Rio Grande do Sul-Brazil, in the 2016 growing season. The grapes were harvested from the Cabernet Sauvignon variety of a commercial vineyard located at Latitude $31^{\circ} 01^{\prime} 20.031^{\prime \prime} \mathrm{S}$ and Longitude 54 36"11.655"W, with climate characterized as Cfa subtropical, slightly humid, with cold winter and mild summer, annual precipitation between 1200 and $1500 \mathrm{~mm}$, and average air temperature of 17 to $20^{\circ} \mathrm{C}$. The soil is classified as Vertic Planosol of medium to clayey texture (IBGE, 2017a, 2017b; Rossato, 2011). The vineyard is composed by plants from the clone R5 and rootstock SO4, conducted in a two-wire espalier system, spacing of 1.25 meters $(\mathrm{m})$ between plants and $3 \mathrm{~m}$ between rows, with spore cord pruning, located in an area of 2.5 hectares, and implanted since 1990.

The experimental design was randomized blocks with treatments arranged in three replicates. The treatments consist of eight harvest periods previously planned, being: I (13/01/2016), II (19/01/2016), III (26/01/2016), IV (02/02/2016), V (11/02/2016), VI (16/02/2016), VII (23/02/2016) and VIII (01/03/2016 (industrial harvest). The experimental units were composed by 500 grape berries, which were randomly collected from the upper, middle and lower thirds of the bunches. In order to increase reliability of results and minimize border effects, plants from the vineyard edges were discarded.

The physical-chemical characteristics were measured by manual extraction of the must: Density (DEN): determined in units at 20/20 ${ }^{\circ} \mathrm{C}$ (Ribéreau-Gayon et al., 1976); Glucometric degree (GD): determined in babodegrees; Hydrogenionic potential $(\mathrm{pH})$ : measured in $\mathrm{pH}$ units (Ribéreau-Gayon et al., 1976); Titratable Total Acidity (TA): obtained by titrating in meq $\mathrm{L}^{-1}$ (Amerine \& Ough, 1976); Total polyphenol index (TPI): expressed in g.L1 (Ribéreau-Gayon \& Stonestreet, 1965); Potassium (K): measured by Fourier Transformed Infrared Spectroscopy (FTIR) in $\mathrm{mg} \mathrm{L}^{-1}$; Phenolic maturity index (PMI): measured by maturity percentage (Glories \& Augustín, 1993).

The data were submitted to analysis of variance at 5\% of probability, verifying its assumptions by the Hartley test for variances homogeneity (Ramalho et al., 2012) and normality by Shapiro-Wilk (1969). The significant characters were submitted to complementary analyzes by Tukey at 5\% of probability. Subsequently, the linear correlation was performed in order to reveal tendencies of association between the measured characters. Multiple Stepwise regression was performed, setting potassium concentration in the must $(\mathrm{K})$ and phenolic maturity index 
(PMI) as dependent variables, while the meteorological variables air temperature range (ATR), minimum air temperature (MNT), maximum air temperature (MXT), incident solar radiation (ISR) and rainfall (RF) were considered as independent or explanatory variables of the model.

\section{Results and Discussion}

In the conditions of this study, the meteorological information (Table 1) presented maximum and minimum air temperatures higher than the expected for Dom Pedrito-RS, with rainfall below the historical average. For an adequate quality of grapes and wine making process, the balance of air temperatures and precipitation during the crop cycle is necessary. During maturation, the occurrence of high precipitation rates plus high air temperatures is responsible for high fungal diseases incidence, and a suitable thermal amplitude is required for anthocyanin synthesis. Temperatures above $35{ }^{\circ} \mathrm{C}$ may jeopardize grape quality by degrading anthocyanins (Cheng et al., 2014). Rainfall affects grapes in a qualitative way, and directly influences the productive cycle, asexcessive precipitation results in negative effects and delay of grape maturation (Jackson \& Cherry, 1987). Low rainfall rates during maturation stage increase sugars and alter wine quality (Jackson \& Lombard, 1993).

Table 1. Meteorological variables during trials conduction with Cabernet Sauvignon vines, in Dom Pedrito, RS, Brazil, 2016 growing season

\begin{tabular}{ll}
\hline Variable & Average \\
\hline Maximum temperature $\left({ }^{\circ} \mathrm{C}\right)$ & 30.27 \\
Minimum temperature $\left({ }^{\circ} \mathrm{C}\right)$ & 20.13 \\
Radiation & 1874 \\
Rainfall $(\mathrm{mm})$ & 2.043 \\
Amplitude $\left({ }^{\circ} \mathrm{C}\right)$ & 10.14 \\
\hline
\end{tabular}

Source: INMET (National Institute of Meteorology).

The physical-chemical characters (Table 2) increased during grapes maturation. Regarding must density (DEN) periods VI, VII and VIII revealed superiority over the other harvest periods evaluated, being these periods included in the last 14 days from maturation to harvest. When compared the period I corresponding to veraison, the must presents lower density in relation to the other periods, incrementing density in $1.77 \%$ after period I, due to the synthesis of sugars and accumulation of potassium, polyphenols and other minerals in the grapes. During maturation, the synthesis of sugars and consequent higher potassium accumulation in the grapes is observed (Togores, 2011).

The glucometric degree (GD) evidenced similar tendency to density (DEN). GD is defined as the sugars content in the must, thereby, the evolution of sugars occurs during maturation, and their highest concentrations are evidenced in periods close to industrial harvest (period VIII). Periods VI, VII and VIII correspond to 14 days preceding industrial harvest, these periods presented the highest GD magnitudes compared to the other evaluated periods. When comparing period, I to the others, it is possible to identify an increase of $26 \%$ in glucometric degree. Cabernet Sauvignon presents an increase of sugars after veraison, where the highest magnitudes of these sugars are evidenced at industrial harvest (Navarro et al., 2008).

The hydrogen ionic potential (IP) was higher in periods VII and VIII, which comprise eight days between grapes phenolic maturation and industrial harvest, at this occasion, there was an increment of $20 \%$ of pH magnitude, compared to period I. $\mathrm{pH}$ reveals considerable increases during grapes maturation stage, and its increment is not suitable for producing a high-quality wine under this study's conditions. In view of this, the magnitudes verified were due to the presence of tartaric and malic acid in the grapes and must, there is a tendency to increase $\mathrm{pH}$ during maturation through degradation of malic acid and reduction of tartaric acid by its exposure to high temperatures and luminosity, where a fraction of theirs is reused for sugar biosynthesis. Many $\mathrm{pH}$ related factors such as acidity, potassium, malic and tartaric acid proportions are determinants for $\mathrm{pH}$ magnitude (Conde et al., 2007). 
Table 2. Physic-chemical analyses of Cabernet Sauvignon must from Dom Pedrito, RS, 2016 growing season

\begin{tabular}{lllllll}
\hline Period & DEN $\left(20 / 20^{\circ} \mathrm{C}\right)$ & GD $\left({ }^{\circ} \mathrm{Babo}\right)$ & $\mathrm{PH}(\mathrm{pH})$ & TTA $\left(\mathrm{meq} \mathrm{L}^{-1}\right)$ & $\mathrm{K}\left(\mathrm{mg} \mathrm{L}^{-1}\right)$ & $\left.\mathrm{TPI}_{(\mathrm{g} \mathrm{L}}^{-1}\right)$ \\
\hline I & $1.0686 \mathrm{e}$ & $14.217 \mathrm{e}$ & $3.3233 \mathrm{e}$ & $187.77 \mathrm{a}$ & $565.7 \mathrm{f}$ & $15.50 \mathrm{bc}$ \\
II & $1.0737 \mathrm{~d}$ & $15.230 \mathrm{~d}$ & $3.4633 \mathrm{~d}$ & $164.13 \mathrm{~b}$ & $834 \mathrm{e}$ & $15.30 \mathrm{bc}$ \\
III & $1.0786 \mathrm{c}$ & $16.163 \mathrm{c}$ & $3.47 \mathrm{~d}$ & $129.70 \mathrm{c}$ & $950 \mathrm{de}$ & $13.767 \mathrm{c}$ \\
IV & $1.0821 \mathrm{~b}$ & $16.853 \mathrm{~b}$ & $3.7267 \mathrm{c}$ & $106.60 \mathrm{~d}$ & $1042.7 \mathrm{~d}$ & $15.60 \mathrm{bc}$ \\
V & $1.0764 \mathrm{~cd}$ & $15.757 \mathrm{c}$ & $3.6833 \mathrm{c}$ & $93.73 \mathrm{e}$ & $967 \mathrm{de}$ & $17.433 \mathrm{ab}$ \\
VI & $1.0855 \mathrm{a}$ & $17.507 \mathrm{a}$ & $3.8367 \mathrm{~b}$ & $85.40 \mathrm{ef}$ & $1492.3 \mathrm{c}$ & $16.70 \mathrm{abc}$ \\
VII & $1.0857 \mathrm{a}$ & $17.547 \mathrm{a}$ & $3.9467 \mathrm{a}$ & $82.60 \mathrm{f}$ & $1716.7 \mathrm{~b}$ & $18.633 \mathrm{a}$ \\
VIII & $1.0875 \mathrm{a}$ & $17.880 \mathrm{a}$ & $3.9767 \mathrm{a}$ & $82.37 \mathrm{f}$ & $2335.7 \mathrm{a}$ & $18.067 \mathrm{a}$ \\
\hline
\end{tabular}

Note. Means followed by the same uncapitalized letter in the column do no statistically differ by Tukey test at $5 \%$ of probability. DEN: density; GD: glucometric degree; PH: hydrogen ionic potential; TTA: titratable total acidity; K: potassium; TPI: total polyphenols index.

The total acidity (TA) reduced during maturation, which was minimized in periods VI, VII and VIII. These periods comprise the last 14 days between grapes maturation stageand its harvest. When comparing period I, of higher acidity, until harvest, it was observed $56 \%$ of reduction in TA's magnitude. By reducing total acidity, the decrease of malic and tartaric acid synthesis is expected, which are influenced by air temperature and luminosity increases (Kliewer, 1967; Johson \& Nagel, 1976; Matsui et al., 1979). During grapes maturation, the highest degradation rate of malic acid is verified, which indirectly minimizes the concentration and synthesis of this acid, being inversely proportional to air temperature increase (Rizzon \& Sganzerla, 2007). The tartaric acid reduction at maturation stage results from the breaking down and synthesis of new sugars (Togores, 2011).

The potassium concentration (K) was increased as function of the crop development throughout periods VI, VII and VIII, being period VIII responsible for the greatest potassium accumulation in grapes, thus, harvest and industrial winemaking of this variety was proceeded. From the beginning of the study until the harvest, it was identified an increase of $313 \%$ of potassium accumulation in grapes. Studies indicate that potassium accumulation occurs during the entire grapevine reproductive period, however, it is boosted during maturation (Mpelasoka et al., 2003). Potassium is translocated to grapes by xylem and phloem vessels, it does not go through metabolization process, and theoretically, potassium accumulation in grapes is similar to its magnitude supplied to the plants through fertilization. However, characteristics of the variety used, soil, microclimate, and rootstock must be considered (Mpelasoka et al., 2003).

The potassium magnitudes in the must were not adequate, because during wine stabilization, this macronutrient binds to tartaric acid $(\mathrm{H} 2 \mathrm{~T})$, and causes a certain precipitation forming potassium bitartrate $\left(\mathrm{C}_{4} \mathrm{H}_{6} \mathrm{O}_{5} \mathrm{~K}\right)$. This physiological phenomenon results in wines with decreased acidity and higher $\mathrm{pH}$, and these effects were physiologically proven in Cabernet Sauvignon by Davies et al. (2006). High potassium concentrations in winemaking forms potassium bitartrate, reducing the availability of tartaric acid and increasing total acidity of the wine (Ribérau-Gayon et al., 2003). Elevated magnitudes minimize microbial stability and potentiate wines oxidation (Fernández-Cano \& Togores, 2011).

Regarding total polyphenols index (TPI), an irregular variation during maturation was verified, being the largest magnitudes observed in periods VII and VIII. The increase of total polyphenols at the end of maturation resulted in an increase of anthocyanins. These effects increased wines total polyphenols in $35 \%$, due to the synthesis of anthocyanins during maturation, and enzymatic action. When suitable magnitudes of total polyphenols are achieved, it is possible to obtain high-quality wines, influencing features such as color, body, astringency and natural antioxidants content (Zamora, 2003; Conde et al., 2007). It is possible to determine total polyphenols magnitudes in the grapes, in this study, values were verified within standard parameters for high-quality wines. In this context, increase in total polyphenols was determined by enzymatic action of phenylalanine ammonia lyase (PAL), which has fundamental role in the conversion of phenylalanine to cinnamic acid, the responsible for formation of simple phenolic precursors that are transformed into phenolic compounds, flavonoids and stilbenes (Conde et al., 2007).

The monitoring of phenolic maturation required a comprehension of total potential and extractable potential of anthocyanins present in the grapes. The anthocyanins in solution ApH 1.0 and ApH 3.2 (Table 3) refer to the quantity of anthocyanins in the solution, as $\mathrm{ApH} 1.0$ refers to the total of anthocyanins present in the grapes, and ApH 3.2 determines the proportion of anthocyanins that may be extracted in wine making. Regular variations 
were not verified during phenolic maturation, and the most adequate magnitudes occurred during period IV, referring to 27 days before the harvest.

Table 3. Total polyphenol index, total anthocyanins, extractible anthocyanins of Cabernet Sauvignon from Dom Pedrito, RS, 2016 growing season

\begin{tabular}{llll}
\hline \multirow{2}{*}{ Period } & TPI & \multicolumn{2}{c}{ Anthocyanins $\left(\mathrm{mg} \mathrm{L}^{-1}\right)$} \\
\cline { 3 - 4 } & & ApH 1.0 & ApH 3.2 \\
\hline I & $15.50 \mathrm{bc}$ & $362.25 \mathrm{ab}$ & $150.79 \mathrm{ab}$ \\
II & $15.30 \mathrm{bc}$ & $385.00 \mathrm{a}$ & $152.83 \mathrm{ab}$ \\
III & $13.77 \mathrm{c}$ & $389.38 \mathrm{a}$ & $149.34 \mathrm{ab}$ \\
IV & $15.60 \mathrm{bc}$ & $390.83 \mathrm{a}$ & $161.29 \mathrm{a}$ \\
V & $17.43 \mathrm{ab}$ & $333.50 \mathrm{ab}$ & $131.84 \mathrm{ab}$ \\
VI & $16.70 \mathrm{abc}$ & $350.30 \mathrm{ab}$ & $139.71 \mathrm{ab}$ \\
VII & $18.63 \mathrm{a}$ & $269.79 \mathrm{~b}$ & $114.05 \mathrm{~b}$ \\
VIII & $18.07 \mathrm{a}$ & $345.34 \mathrm{ab}$ & $154.00 \mathrm{ab}$ \\
\hline
\end{tabular}

Note. Means followed by the same uncapitalized letter in the column do no statistically differ by Tukey test at $5 \%$ of probability. TPI: total polyphenol index; $\mathrm{ApH} 1.0$ : total anthocyanins; ApH 3.2: extractible anthocyanins.

Phenolic maturation (FMI) was irregular (Table 4) throughout the Cabernet Sauvignon maturation, this variety did not show an adequate cell maturation index (PMI\%) at the current growing conditions. This index represents the anthocyanins that were not extracted in the process (Zamora, 2003), therefore, this character did not differentiate according to the evaluation periods. An optimum cell maturation is expected at levels between 70 to $20 \%$, and for harvesting, magnitudes below 30\% are prioritized (Zamora, 2003). Cell maturation determined that the grapes did not present adequate phenolic maturation for harvest under the experimental conditions, due to the extraction of tannins from seeds (DPEP\%) and skin (DPELL\%). In this context, grapesare considered mature when the extractability of tannins from the seeds is lower, and from the skins is superior (Glories and Augustin, 1993). The percentage of tannins in the seeds proves that phenolic maturation was not adequate, as this percentage was 64\%. Zamora (2003) defined levels below 30\% as optimal for this character. Researches determine that cellular maturation indexes and tannins from seeds must be minimized throughout maturation (Ribéreau-Gayon et al., 2006). This condition was not observed in this study because the tannin contents in the seeds evidenced low polymerization, negatively influencing wines sensorial quality.

Table 4. Phenolic maturation index (PMI\%), tannins from seeds (DPEP\%), and tannins from skin (DPELL\%), in Cabernet Sauvignon grapes from Dom Pedrito, RS, 2016 growing season

\begin{tabular}{llll}
\hline Periods & PMI\% & DPELL\% & DPEP\% \\
\hline I & $58.15 \mathrm{a}$ & $38.893 \mathrm{abc}$ & $61.107 \mathrm{bc}$ \\
II & $60.107 \mathrm{a}$ & $39.957 \mathrm{ab}$ & $60.043 \mathrm{bc}$ \\
III & $61.61 \mathrm{a}$ & $43.493 \mathrm{a}$ & $58.77 \mathrm{c}$ \\
IV & $58.827 \mathrm{a}$ & $41.21 \mathrm{ab}$ & $58.79 \mathrm{c}$ \\
V & $58.953 \mathrm{a}$ & $30.327 \mathrm{~cd}$ & $69.673 \mathrm{ab}$ \\
VI & $60.163 \mathrm{a}$ & $32.747 \mathrm{bcd}$ & $67.253 \mathrm{abc}$ \\
VII & $57.553 \mathrm{a}$ & $24.467 \mathrm{~d}$ & $75.533 \mathrm{a}$ \\
VIII & $55.087 \mathrm{a}$ & $34.443 \mathrm{abc}$ & $65.557 \mathrm{abc}$ \\
\hline
\end{tabular}

Note. Means followed by the same uncapitalized letter in the column do no statistically differ by Tukey test at 5\% of probability. PMI: phenolic maturation index; DPELL: index of tannins extracted from skins; DPEP: index of tannins extracted from seeds.

This research exposed important correlations (Table 5), where sugars and density were positively associated with potassium, likewise, sugars expressed positive correlation with must density. Potassium is involved in the translocation and transport of sugars from the plant to grapes, this translocation occurs through phloem and xylem, thus, it is assumed that potassium is closely related to soluble sugars and the coloring of grapes (Togores, 
2011). It was possible to identify a relation between glucometric degree with total polyphenols and $\mathrm{pH}$, in contrast, inverse associations with total acidity.

Table 5. Pearson's correlationbetween meteorological variables, phenolic maturation, and physic-chemical parameters of must from Cabernet Sauvignon grapes produced in Dom Pedrito, RS, 2016 agricultural year

\begin{tabular}{|c|c|c|c|c|c|c|c|c|c|c|c|c|c|}
\hline & MXT & MNT & ISR & $\mathrm{RF}$ & ATR & DPELL & DPEP & DEN & GD & $\mathrm{PH}$ & TTA & $\mathrm{K}$ & TPI \\
\hline PMI & $\begin{array}{l}-0.29 \\
\end{array}$ & 0.16 & -0.19 & 0.05 & -0.18 & -0.12 & 0.17 & -0.10 & $\begin{array}{l}-0.08 \\
\end{array}$ & -0.19 & -0.19 & -0.23 & $\begin{array}{l}-0.22 \\
\end{array}$ \\
\hline MXT & - & 0.36 & 0.17 & 0.06 & 0.34 & -0.33 & 0.27 & -0.24 & -0.25 & -0.04 & 0.08 & -0.20 & 0.20 \\
\hline MNT & & - & -0.30 & $0.45^{*}$ & $-0.75^{* *}$ & -0.22 & 0.24 & -0.31 & -0.31 & -0.19 & 0.11 & $0.50^{*}$ & 0.22 \\
\hline ISR & & & - & $-0.45^{*}$ & $0.43^{*}$ & 0.10 & -0.05 & -0.13 & -0.13 & -0.01 & 0.21 & 0.02 & -0.17 \\
\hline $\mathrm{RF}$ & & & & - & $-0.47^{*}$ & $-0.44 *$ & $0.56^{*}$ & $0.56^{*}$ & $0.56^{*}$ & $0.53^{*}$ & $-0.58 *$ & $0.62 *$ & 0.40 \\
\hline ATR & & & & & - & -0.01 & -0.05 & 0.14 & 0.13 & 0.16 & -0.05 & 0.26 & -0.08 \\
\hline DPELL & & & & & & - & $-0.98^{* *}$ & $-0.43 *$ & $-0.42 *$ & $-0.62 * *$ & $0.56^{* *}$ & $-0.46^{*}$ & $-0.77 * *$ \\
\hline DPEP & & & & & & & - & $0.43^{*}$ & $0.42 *$ & $0.61^{* *}$ & $-0.56^{* *}$ & $0.45^{*}$ & $0.72 * *$ \\
\hline DEN & & & & & & & & - & $0.99 * *$ & $0.92 * *$ & $-0.90^{* *}$ & $0.87^{* *}$ & $0.49 *$ \\
\hline GD & & & & & & & & & - & $0.92 * *$ & $-0.90^{* *}$ & $0.87 * *$ & $0.48^{*}$ \\
\hline $\mathrm{PH}$ & & & & & & & & & & - & $-0.92 * *$ & $0.89^{* *}$ & $0.68^{* *}$ \\
\hline TTA & & & & & & & & & & & - & $-0.76^{* *}$ & $-0.57^{* *}$ \\
\hline K & & & & & & & & & & & & - & $0.62 * *$ \\
\hline
\end{tabular}

Note. ${ }^{* *},{ }^{*}$ : Significant at 1 and $5 \%$ of probability by the $\mathrm{t}$ test.

PMI: phenolic maturation index; MXT: maximum air temperature; MNT: minimum air temperature, ISR: incident solar radiation; RF: rainfall; ATR: air temperature range; DPELL: tannins from skins; DPEP: tannins from seeds; DEN: density; GD: sugars; PH: hydrogen ionic potential TTA: titratable total acidity; K: potassium; TPI: total polyphenol index.

The increase in potassium content occurred due to the more alkaline $\mathrm{pH}$, however, there are doubts about potassium translocation dynamics tograpes and their effect on $\mathrm{pH}$ manifestation. According to Davies et al. (2006), the pH of Cabernet Sauvignon and Shiraz grapes was influenced by the amount of available and absorbed potassium, these inferences corroborate with those obtained in this study. Therefore, it is understood the need for in-depth studies on the physiological dynamics of potassium accumulation and its effects on the hydrogen ionic potential of grapes.

The $\mathrm{pH}$ presented an inverse association with tannins present in the skins, and positive correlation between tannins present in the seeds, density and sugars. Similarly, potassium was associated in the same direction with total polyphenol content, due to the increment of the skins covering grapes and seeds. It is expected that the higher extraction of compounds from the skinsand near the seeds increases potassium concentration in the must.This high potassium concentration occurs in the skins, followed by seeds and pulp (Togores, 2011). The accumulation of potassium was positively associated with rainfall and minimum air temperature.

The potassium content, $\mathrm{pH}$, sugars, density and percentage of tannin extracted from the seeds are positively associated with rainfall. In contrast, total acidity and percentage of tannin extracted fromskins correlate in opposite directions. Similarly, potassium content was inversely proportional with minimum air temperature. The $\mathrm{pH}$ revealed inverse association withApH 1.0 (Table 6), being these responsible for the (ApH 1.0) total potential of anthocyanins present in grapes. This character is considered a parameter of importance for grapes phenolic maturation. In view of this, potassium was positively correlated with $\mathrm{pH}$, however, its dynamics should still be elucidated for Cabernet Sauvignon phenolic maturation. 
Table 6. Pearson's correlation between total anthocyanins, extractible anthocyanins, $\mathrm{pH}$ and potassium in must from Cabernet Sauvignongrapes produced in Dom Pedrito, RS, 2016 agricultural years

\begin{tabular}{lllll}
\hline & ApH 1.0 & ApH 3.2 & PH & K \\
\hline ApH 1.0 & - & $0.61^{* *}$ & $-0.50^{*}$ & -0.37 \\
ApH 3.2 & & - & -0.33 & -0.15 \\
PH & & & - & $0.89 * *$ \\
K & & & & - \\
\hline
\end{tabular}

Note. ${ }^{* *}, *$ : Significant at 1 and $5 \%$ of probability by the $\mathrm{t}$ test.

$\mathrm{ApH}$ 1.0: total anthocyanins potential; $\mathrm{ApH}$ 3.2: extractible anthocyanins; $\mathrm{PH}$ : hydrogen ionic potential;K: potassium.

The predictive multiple regression analysis of Step wise (Table 7) was performed, setting potassium content and phenolic maturation index as dependent characters and of interest for prediction. On the other hand, meteorological variables were classified as explanatory or independent. The equations presented an adjusted coefficient of determination $\left(\mathrm{R}^{2}\right)$ of 0.34 and 0.41 respectively, being these equationsreliable,as the oscillation ofprecision parameters is due to pre-defined interrelationship between a dependent characterandmeteorological variables subjected to oscillation andseasonality.

Table 7. Stepwise predictor models for potassium and phenolic maturation index inCabernet Sauvignongrapes from Dom Pedrito, RS, 2016 growing seasons

\begin{tabular}{lll}
\hline & Predicted models & $\mathrm{R}^{2}$ \\
\hline Potassium & $1449.31-135.08 \cdot \mathrm{MXT}+147.16 \cdot \mathrm{MNT}-0.31 \cdot \mathrm{ISR}+36.13 \cdot \mathrm{RF}$ & 0.4075 \\
PMI & $41.75795+0.62097 \cdot \mathrm{MXT}-0.26559 \cdot \mathrm{RF}+2.39855 \cdot \mathrm{ATR}$ & 0.3416
\end{tabular}

Note. MXT: maximum air temperature; MNT: minimum air temperature; ISR: incident solar radiation; RF: rainfall; ATR: air temperature range.

The model shows that magnitudes of potassium accumulated in grapes is determined by the effects of maximum and minimum air temperature, incident solar radiation and accumulated rainfall, stating that minimum air temperature is more relevant than the others. Therefore, the plants subjected to higher minimum air temperatures tend to increment potassium accumulation in the grapes. Among the analyzed variables, incident solar radiation less contributed to determine grapes potassium concentration. Research by Fernández and Togores (2011) affirmed that incident solar radiation influences the grapevine microclimate, potassium accumulation in the grapes, being clear the relation between the increase of vines photosynthetic rate and the lower potassium accumulation in grapes. The rainfall index increase was responsible for greater potassium accumulation in the grapes, therefore, the availability of water in the soil results in higher potassium availability and uptake by the vine root system. Thus, greater thermal amplitude caused by the incident solar radiation on the canopy modifies the photosynthetic dynamics, and its effects reflect on assimilated and nutrient translocations by the plant conducting vessels, therefore, potassium availability, uptake and translocation by the plant increase its accumulation in the grapes, must and wine (Freeman \& Kliewer, 1983; Hepner \& Bravdo, 1985; Mpelasoka et al., 2003).

\section{Conclusion}

The periods preceding grapes phenolic maturation directly influence the physical and chemical conformity of must and wine.Potassium, $\mathrm{pH}$ and total acidity directly influence the poorphenolic maturation of Cabernet Sauvignon. Minimum and maximum air temperature, thermal amplitude, incident solar radiation and accumulated rainfall interfere in the photosynthetic dynamics, potassium accumulation in the grapes and phenolic maturation of Cabernet Sauvignon.

\section{References}

Amerine, M. A., \& Ough, C. S. (1976). Análisis de vinos y mostos (p. 158). Zaragoza: Acríbia.

Cheng, G., He, Y. N., Yue, T. X., Wang, J., \& Zhang, Z. W. (2014). Effects of climatic conditions and soil properties on Cabernet Sauvignon berry growth and anthocyanin profiles. Molecules, 19(9), 13683-13703. https://doi.org/10.3390/molecules190913683 
Ciotta, M. N., Ceretta C. A., Silva, L. O. S. da, Ferreira, P. A. A., Sautter, C. K., Couto, R. da R., \& Brunetto, G. (2016). Grape yield, and must compounds of 'Cabernet Sauvignon' grapevine in sandy soil with potassium contents increasing. Ciência Rural, 46(8), 1376-1383. https://doi.org/10.1590/0103-8478cr20150472

Conde, C., Silva, P., Fontes, N., Dias, A. C. P., Tavares, R. M., Sousa, M. J., ... Gerós, H. (2007). Biochemical changes throughout grape berry development and fruit and wine quality. Food, 1, 1-22.

Davies, C., Shin, R., Liu, W., Thomas, M. R., \& Schachtman, D. P. (2006). Transporters expressed during grape berry (Vitis vinifera L.) development are associated with an increase in berry size and berry potassium accumulation. Journal of Experimental Botany, 57(12), 3209-3216. https://doi.org/10.1093/jxb/erl091

Fernández-Cano, L. H., \& Togores, J. H. (2011). Tratado de viticultura I (p. 1031). Madrid: Mundi-Prensa.

Freeman, B. M., \& Kliewer, W. M. (1983). Effect of irrigation crop level and potassium fertilization on Carignane vines. II. Grape and wine quality. American Journal of Enology and Viticulture, 34, 197-207.

Giovannini, E. (2001). Cultivares. In E. Giovannini (Ed.), Agroecological Grapes (pp. 76-80). Porto Alegre: Renascença.

Glories, Y., \& Augustín, M. (1993). Maturitéphénolique du raisin, consequences technologiques: Application aux millésimes (pp. 56-61). Actes du Colloque Journée Technique du C.I.V.B., Bordeaux.

Hepner, Y., \& Bravdo, B. (1985). Effect of crop level and drip irrigation scheduling on the potassium status of Cabernet Sauvignon and Carignane vines and its must and wine composition and quality. American Journal of Enology and Viticulture, 36, 140-147.

IBGE (Brazilian Institute of Geography and Statistics). (2017a). Exploratory map of soils from Rio Grande do Sul state. Retrieved June 15, 2017, from ftp://geoftp.ibge.gov.br/informacoes_ambientais/pedologia/mapas/ unidades_da_federacao/rs_pedologia.pdf

IBGE (Brazilian Institute of Geography and Statistics). (2017a). Geodesic data. Retrieved June 15, 2017, from http://www.ibge.gov.br/home/geociencias/geodesia/bdgpesq_googlemaps.php

Jackson, D. I., \& Lombard, P. B. (1993). Environmental and management practices affecting grape composition and wine quality-A review. American Journal of Enology and Viticulture, 44(4), 409-430.

Jacobs, S. A., Zocche, R. G. S., Jacobs, B., Zocche, F., Sampaio, N. V., Rizzon, L. A., ... RombaldI, C. V. (2016). Behavior oh phenolic and color parameters during grape vinification of Tannat and Cabernet Sauvignon cvs.inBagé-RS. International Journal of Current Research, 8(7), 34863-34867.

Jacskon, D. I., \& Cherry, N. J. (1987). Prediction of a district's grape-ripening capacity using a latitude-temperature index (LTI). American Journal of Enology and Viticulture, 39(1), 19-28.

Kishino, A. Y., \& Marur, I. P. H. (2007). Fatores climáticos e o desenvolvimento da videira. In A. Y. Kishino, S. L. C. Carvalho, \& S. R. Roberto (Eds.), Viticultura tropical (pp. 59-86). Londrina: IAPAR.

Kliewer, W. M., Howarth, L., \& Omori, M. (1967). Concentrations of tartaric acid, malic acid and their salts in Vitisvinifera grapes. American Journal of Enology and Viticulture, 18(1), 42-54.

Leão, P. C. S., \& Silva, E. E. G. (2003). Phenologic characterization and thermal requirement of seedless grape varieties at the São Francisco Valley. Brazilian Journal of Fruticulture, 25(3), 379-382.

Mpelasoka, B. S., Schachtman, D. P., Treeby, M. T., \& Thomas, M. R. (2003). A review of potassium nutrition in grapevines with special emphasis on berry accumulation. Australian Journal of Grape and Wine Research, 9(3), 154-168. https://doi.org/10.1111/j.1755-0238.2003.tb00265.x

Navarro, S., León, M., Roca-Pérez, L., Boluda, R., García-Ferriz, L., Pérez-Bermúdez, P., \& Gavidia, I. (2008). Characterisation of Bobal and Crujidera grape cultivars, in comparison with Tempranillo and Cabernet Sauvignon: Evolution of leal macronutrients and berry composition during grape ripening. Food Chemistry, 108, 182-190. https://doi.org/10.1016/j.foodchem.2007.10.060

Ortín, A. B. B. (2005). Técnicas enológicas para la obtención de vinos de Monastrell de alto contenido polifenólico [p. 297, Tese (Doutorado), Universidad de Murcia, Murcia].

Ramalho, M., Santos, J. B., Pinto, C. B., Souza, E. A., gonçalves, F. M. A., \& Souza, J. C. (2012). Genetics in agriculture (p. 566). Lavras, Brazil.

Ribérau-Gayon, P., Glories, Y., Maujean, A., \& Dubourdieu, D. (2003). Tratado de Enologia: Quimicadelvino, estabilización y tratamentos (p. 537). Buenos Aires: Hemisfério Sur. 
Ribéreau-Gayon, P., \& Stonestreet, E. (1965). Dosage des anthocyanesdans les vines rouge. Bulletin de laSocietéChimiquede France, 9, 2649-265.

Ribéreau-Gayon, P., Debourdieu, D., \& Maujean, A. (2006). Handbook of enology: The chemistry of wine stabilization and treatments. John Wiley \& Sons Ltd., Estados Unidos. https://doi.org/10.1002/0470010398

Rizzon, L. A., \& Miele, A. (2002). Evaluation of the cv. Cabernet Sauvignon in the manufacture of red wine. Food Science and Technology, 22(2), 192-198. https://doi.org/10.1590/S0101-20612002000200015

Rizzon, L. A., \& Miele, A. (2002). The acidity in the vinification of Isabella, Cabernet Sauvignon, and cabernet franc red grapes. Rural Science, 32(3), 511-515. https://doi.org/10.1590/S0103-84782002000300023

Rizzon, L. A., \& Sganzerla, V. M. A. (2007). Tartaric and malic acids in the must grapes of Bento Gonçalves-RS, Brazil. Rural Science, 37(3), 911-914. https://doi.org/10.1590/S0103-84782007000300053

Rossato, M. S. (2011). Climates of Rio Grande do Sul: Variability, tendencies and tipology [p. 240, Thesys (Doctorate), Federal University of Rio Grande doSul, Brazil].

Shapiro, S. S., \& Wilk, M. B. (1965). An Analysis of Variance Test for Normality (Complete Samples). Biometrika, 52(3/4), 591-611. https://doi.org/10.1093/biomet/52.3-4.591

Sinimbu, F. (2017). Scientists help the Campanha Gaúcha to obtain seal of origin for wines. Retrieved June 15, 2017, from https://www.embrapa.br/busca-de-noticias/-/noticia/6031942/cientistas-ajudam-campanha-gauc ha-a-obter-selo-de-procedencia-para-vinhos

Togores, J. H. (2011). Tratado de Enología I (p. 975). Madrid: Mundi-Prensa.

Walker, R. R., \& Blackmore, D. H. (2012). Potassium concentration and pH inter-relationships in grape juice and wine of Chardonnay and Shiraz from range of rootstocks in differents environments. Australian Journal of Grape and Wine Research, 18(2), 183-193. https://doi.org/10.1111/j.1755-0238.2012.00189.x

Zamora, F. (2003). Elaboración y crianza del vino tinto: Aspectos científicos y práticos (p. 225). Madrid: Mundi-Prensa.

Zanette, T., Santana, D. R., Selli, G. T., Giacomelli, S. R., Datsch, V. C., Datsch, A. C., ... Souza, V. Q. (2016). Determination of the antioxidant activity of red and white wines produced in Riogrande do Sul, Brazil. International Journal of Current Research, 8, 36710-36713.

Zanus, M. C., \& Tonietto, J. (2012). Methodological elements for sensorial characterization of wines from wine regions. In J. Tonietto, V. S. Ruiz, \& V. D. Gómez-Miguel (Eds.), Clima zonificación y tipicidade del vino em regiones vitivinícolas iberoamericanas (pp. 39-46). Cyted: Madrid.

Zocche, R. G. S., Jacobs, S. A., Sampaio, N. V., Souza, V. Q., Carvalho, I. R., Nardino, M., ... Rombaldi, C. V. (2017). Wines produced with Cabernet Sauvignon grapes from region of Bagé in the state of Rio Grande do Sul, Brazil. Brazilian Journal of Agricultural Research, 52(5), 311-318. https://doi.org/10.1590/s0100-204x 2017000500004

Zocche, R. G. S., Jacobs, S. A., Souza, V. Q., Nardino, M., Carvalho, I. R., Rombaldi, C. V., ... Rizzon, L. A. (2016a). Wine characterization from Merlot, Tannat and Cabernet Sauvignon grapes of the Campanha Region of RS, harvested in two maturation stages. International Journal of Current Research, 8, 33078-33086.

Zocche, R. G. S., Jacobs, S. A., Souza, V. Q., Nardino, M., Carvalho, I. R., Rombaldi, C. V., ... Rizzon, L. A. (2016b). Characterization of Cabernet Sauvignon wine made with grapes from Campanha RS Region. African Journal of Agricultural Research, 11, 4262-4268. https://doi.org/10.5897/AJAR2016.11076

\section{Copyrights}

Copyright for this article is retained by the author (s), with first publication rights granted to the journal.

This is an open-access article distributed under the terms and conditions of the Creative Commons Attribution license (http://creativecommons.org/licenses/by/4.0/). 